\title{
Fiedler and Chemers Revisted; Understanding the Implications of the Least Preferred Co-worker Scale
}

\author{
K.R. Howell* \\ Department of Art, Appalachian State University, Boone, North Carolina, USA \\ *Corresponding author: howellkr@appstate.edu
}

\begin{abstract}
The importance of succession planning and choosing the right candidate for the job cannot be underestimated. Having a conceptual framework for clear and honest evaluation of a candidate for an open position is a key factor in choosing the "best" one. Fiedler and Chemers work provides one matrix for determining a fit in terms of their Least Preferred Co-Worker scale. It is easy to check off minimum thresholds for education and experience. The evaluation of "fit" for the job is subjective and often laborious task. While many factors contribute to the success of a person in their job, the idea of knowing the best fit for a given situation is a credible and many times key assessment in selecting the eventual employee. The aim of this paper is to immerse the participants in a situation where they must determine the overall environment through the lens of Fiedler and Chemers' Contingency Theory and select a new leader for the organization.
\end{abstract}

Keywords: executive succession, Least Preferred Co-worker, contingency theory, leadership

Cite This Article: K.R. Howell, "Fiedler and Chemers Revisted; Understanding the Implications of the Least Preferred Co-worker Scale." Journal of Business and Management Sciences, vol. 6, no. 3 (2018): 82-85. doi: 10.12691/jbms-6-3-3.

\section{Introduction}

The primary subject matter for this case is executive succession, along with the leadership and management theories that are required for replacing a leader. The setting is a community college that has experienced some financial issues. The College has a seasoned President and an experienced set of senior leaders. The case has a difficulty level of 4 and is designed for senior level and first year graduate students in leadership, management and organizational theory. The case is designed for delivery in a one and one-half hour class with no more than two hours preparation.

\section{Case Synopsis}

Northwest Community College is in the midst of a scandal. There is some financial mismanagement that has resulted in severe deterioration of campus morale. The founding President has taken the brunt of the criticism for the current situation and has been relieved of his duties. Three finalists are invited to campus for interviews and meetings with the campus community. They are very different. The committee needs a method for choosing the best replacement for the embattled President.

\section{Reflection}

Dr. Kramer walked across the campus with a nostalgic feeling. The surge in creation of community colleges in the 1960's led him to lobby for one to be placed in his hometown of Lansing, South Carolina. This year would see his 45th anniversary as the President of Northwest Community College. The economic downturn of the first decade of the 21 st century had taken its toll on the community and the college. Many of the factories in the region had reduced workforces or even closed. Much of the private money had dried up. The first signs of problems started to appear as budgets began to get tighter. Several departments began to be looked at more closely. No one seemed to understand exactly the role that each employee had on the campus. There was a time that everyone had specific jobs that were clearly defined. Now people just seemed to work in general areas.

The Dean of Business Affairs, Doris Oliver, had a traditional role at Northwest. She had supervisory roles over the non-academic side of the college. Of particular interest was the painting, electrical and printing groups on the campus. Doris seemed to always have budget for special projects. The last audit showed 3.5 million dollars in a Dean's Discretionary fund.

The State department of Community Colleges scheduled a meeting with Dr. Kramer to discuss the upcoming budget. It happened that the audit results came in just before the meeting. Dr. Kramer couldn't justify any of his requests to the state for special allocations. Every line item that he requested, the executive board kept bringing up all of these excess funds.

Northwest Community College held an emergency board meeting to relay the results of the budget meeting at the state office. Dr. Kramer asked that Dr. Oliver come early to discuss a few things. When he asked about the excess funds, she became very defensive. Her division had 
earned those funds and was entitled to keep all of it. Dr. Kramer asked how her division had "earned" the funds. She replied that it was a result of the work her people had done. Her use of the word "earned" stuck in Dr. Kramer's head and would be a critical mistake on her part.

The meeting was somber as Dr. Kramer relayed the information that every request from the college had been denied. Everyone present asked the same question in different ways. "What could Northwest have done to draw the ire of the State Office? Dr. Kramer denied knowing the exact reason that the requests were denied. He alluded to needing to gather more information. All of the Deans left the meeting shaking their heads about how this could happen.

\subsection{The Root of the Problem}

Dr. Kramer returned to his office and started looking at the data. Dr. Oliver had so much money in an account that seemed to grow and grow. The rest of the campus was barely scraping by. He started looking at the staffing in the electrical department. Nothing looked out of the ordinary. There were ten individuals in the department. All of them had salaries that were in the middle of the range for their job title except for a few "old timers" who were at the top of the scale. He moved on to the paint and facilities department. The story was the same. There were a few people that were near the top of the scale, but most were in the middle. When he looked at campus printing, the picture remained unchanged. He pulled some receipts from work done for the office of the President. The charges didn't look exorbitant. In fact, they looked better than some of the prices he had paid for some work he had hired done at his home. That is when it hit him. The workers were being paid by the hour from state funds. The departments on campus were being billed for time and materials for the work being done. Basically, Dr. Oliver had a staff of workers being paid by the state and she was charging hourly rates to the departments. All of the revenue for the time worked was a transfer of funds from one department to a discretionary fund for Dr. Oliver. Everyone knew how often that she traveled. They all knew how well appointed the offices in her areas were. They just assumed that she was just very judicious in her budgeting.

Dr. Kramer walked across campus to Dr. Oliver's office. He had been in her office a thousand times and had never paid much attention to just how nice everyone's workspace seemed to be. Dr. Oliver's office was even nicer than his own. The office was covered with wood paneling and mahogany furniture. He got right to the point with her. "It looks like you have been collecting time charges from all of your clients even though your workers were being paid from state funds." He cautioned, "All of these years, you have been charging time and materials and you were double dipping on the time." I don't know how that I could not have seen this going on. Every year your budgets always looked better than everyone else's. Now I see it. Starting now all of your workers have to be paid from your internal budget. You can consider the state fund empty. Dr. Oliver said that she didn't see anything wrong with the practice. Dr. Kramer debated on exactly how to terminate Dr. Oliver. He knew it would not be easy.
Dr. Oliver knew the faculty handbook well and understood due process. He met with Dr. Oliver again and explained the storm that was approaching because of her situation. She decided to take the path of least resistance. A week passed and Dr. Kramer got an email announcing Dr. Oliver's retirement. He wanted to redistribute the funds to the various departments on campus. He met with the Dean's council to explain where the newfound resources had been found. He hoped that the new funding would somewhat blunt the news of where it came from. He was not so fortunate.

Angry was not the extent of the feelings expressed in the meeting. It was more akin to outrage. Dr. Abee, Dean of the College of Business summed up the problem. "Did this really happen? Talk about a sweetheart deal. I would love to open a business where someone else pays all of the bills, salary and retirement for the workers. Then, let me keep all of the revenue. They didn't even need an accounts payable ledger because they didn't have anything to pay for."

The outrage in the Dean's council didn't stop there. It moved over the campus like a plague. Dr. Kramer must have been a fool to have not caught this. He must have been a bigger fool if he knew it was going on. The Dean of Fine Arts, Dr. Cavanaugh started the direct attack on the Administration. He said that programs in his division were so underfunded that faculty were buying oils and brushes out of pocket for their intro classes. The Dean continued on "How many majors have we lost because of this perpetual mismanagement? Students come in and see this low budget shoestring operation and ask themselves "Why would I want to make a career of doing this?" This didn't happen overnight. This is years of mismanagement and or deception on the part of the administration.

\subsection{The End is Near}

After a couple of posts in social media, the local paper started looking into the situation. The story ran on the front page below the fold. It claimed that Dr. Kramer had stayed on well past his time with the college. It went on to talk about the allegations of poor financial oversight and cronyism in the office of the president. In a way it was the public beginning of the end for Dr. Kramer. The President of the Community College System summoned Dr. Kramer to her office. Dr. Nichols was relatively new to the job. In fact, Dr. Kramer had been President of Northwest longer than she had been on this earth. She asked Dr. Kramer for the best solution to the current problem. He replied that the situation was dire. Morale is poor, there is little trust between colleagues and a complete distrust of all administration. Students are complacent with their fees and lab bills. Every day is a little worse than the previous one.

Dr. Nichols appreciated the honesty in his response. She talked for a few minutes about how special his contributions have been. She hoped that her genuine words would soften the next blow. "I think it is time for us to change directions at Northwest." Dr. Kramer knew why he was here. He knew that he would leave here without his job.

The search would commence immediately. Hopefully, a change at the top would usher in a new era at Northwest. 


\section{The Candidates}

The three finalists for the office of the president were announced. They visited campus, made presentations, shook hands, toured labs and dined with faculty, staff and students. There were many comments about the diversity of the candidate's backgrounds.

Dr. Alan Cockerham was a Dean from the nearest State University. He was very knowledgeable about the area and opportunities the local industries provided. He talked at length about how he used the shared governance mentality in decision making. He vowed complete transparency in budgeting, staffing and everything that comes across his desk. He even mentioned that he wants to build consensus in every decision.

His personal demeanor was very jovial. He seemed to entertain everyone with whom he came in contact. During his presentation he talked about the personal ties that he plans to build. "If I am your next President, we will be a family. Not just a family, but a close family. I want to set up celebrations at least twice a year similar to a company picnic and frequent outings at the President's Residence. As he left campus he seemed like a politician leaving a rally.

The second candidate was Dr. Lewis Shepherd. He is currently the President of Lakeshore Community College in Yuma, Arizona. This was his third time around as President of a Community College. His schedule was very similar to Dr. Cockerham. He focused on his past accomplishments as a President. All of the schools he has led started in a similar position to Northwest. He was very matter of fact about the current predicament of Northwest. He was very clear about how that he would proceed with rebuilding the trust of the overall campus and community. During his presentation to a large audience he talked about the advantage of having no ties to anyone at the college. "I will come here with no friends, no preconceived notions about you or your programs. My mission is to get your college back on solid ground. I have a history of success in taking care of situations just like yours."

Candidate number three arrived from Los Angeles. Dr. Heather Miller had spent the past 8 years as special assistant to the Chancellor of the California Community College system. Her early childhood was spent 50 miles away in Charlotte, North Carolina. Her presentation focused on her work with coordinating bodies among the vast California Community College System. Her main work was coordinate policy between the Presidents offices at each of the individual community colleges. During the informal meal functions, she talked about her love for the area and the people. Some of the faculty asked about her lack of "Executive" experience. She handled the question well. She had worked with the Chancellor of the California System and even though she had never had that title, she would be able to work with everyone to make the campus a better place to be. Dr. Miller said she understood her strengths and weaknesses. "I am ready to be a President. My interpersonal skills will more than make up for the experience." She was very jovial with the faculty and staff. The comments were about how approachable she seemed to be and how that her demeanor was just what the campus needed to move forward.

\subsection{The Committee}

The committee met to discuss the finalists for the position. The positives and negatives of each candidate were thoroughly discussed. All of the candidates had support from the committee in some way or another. It was a difficult choice. The committee needed some systematic way of determining who had the best chance to pull the college out of its current situation.

\section{Instructor's Notes}

The following section provides guidance in discussing the case with a group.

\subsection{Objectives}

The objectives of the case are to:

1. Develop ways of analyzing the current state of organizational well-being and structure.

2. Understand the ramifications of Leader-Member Relations.

3. Be able to determine level of structure in tasks in a given organization.

4. Develop an understanding of power and rewards structure in a given organization.

5. Be able to recommend the best fit for future success according to Fred Fiedler's Contingency Theory.

6. Be able to determine their own Least Preferred CoWorker (LPC)

7. Utilize the knowledge of their own LPC to determine the organizational conditions for which they are best suited.

\subsection{Recommendations for Teaching Approaches}

Before presenting the case, begin the class by administering the Least Preferred Co-Worker (LPC) instrument found in Northouse Leadership: Theory and Practice; $6^{\text {th }}$ edition page 135 . It is particularly important to introduce the LPC as a way to describe a person that they work least well with. If the participant feels like they are actually evaluating themselves, their tendency will be to skew their responses higher. After the students are comfortable with their own LPC, begin the review of Contingency theory from Northouse 2014. [1,2,4,5,6]

Next, have the class split up into groups of 3-5 and discuss their previous work experience in terms of "Leader Member Relations", "Task Structure" and "Position Power" of their leader. Prompt them to evaluate their direct superior in terms of high LPC or low LPC. Refer to the Fiedler table from Northouse and determine if their leader is a good fit. (See specific questions below)

\subsection{Discussion Questions for Small Groups before the Case is Presented}

1. Think of your work experience. It could be a company, team, church or even the scouts. What is the general attitude toward the leader? Is there trust, respect and admiration? 
Responses here should surround personal experiences. The students should describe their work experiences and rate their "leader member relations" as Good or Poor. $[3,4,10]$

2. In the same organization, how would you characterize the work being done? Is it complex? Can you tell when you are done? Is there many different ways to complete the task?

Responses here should describe the actual work being done. They should result in classifying their work as high structure or low structure as described in the literature. $[4,8]$

3. In the same organization, describe the ability of the leader to reward or punish the workers. Can the leader give a raise or promotion? Can the leader suspend or terminate the workers employment?

The discussion should surround the ability of their leaders to reward or punish the workers. Ultimately they should determine if their leaders have strong or weak power. $[4,8]$

4. According to Fiedler, into which category does your organization fall?

Possible responses should fall into specific situations in organizations as defined by Fiedler. Potential responses should be situation 1 to 8 . $[1,2,4]$

5. Assess your leader in terms of a high, middle or low LPC. Is he/she a good fit for the organization? Responses here will vary widely. Each individual will rate their leader and organization and determine if they are a good fit according to the literature. The Low LPC leaders should be best in most favorable or least favorable situations. High LPC leaders should be best in moderately favorable situations. $[1,2,4]$

\subsection{Discussion Questions after the Case is Presented}

1. Discuss the Leader Member Relations at Northwest Community College.

The most appropriate responses here will surround "Poor Leader Member Relations. This is because of the scandal at Northwest Community College. [1,4]

2. Discuss the Task Structure for the employees at Northwest Community College.

The discussion here will vary. Some students will see education as very structured with clearly defined roles and tasks. Others will see education from a liberal arts perspective with less definition. $[1,2,4,8]$

3. Discuss the Leader Position Power for the President at Northwest Community College.

The discussion here will vary. Some students will see education as the President as CEO and able to punish and reward at will. Others will see the academic enterprise as a process with checks and balances. [1,2,4,7,9]

4. According to Fiedler, what category of leader would be the best fit for Northwest Community College?

Depending on the results of the discussion on the three factors, the community college could be anywhere on the continuum. The most common answer is situation eight. This would indicate a least favorable work environment with poor leader member relations, low task structure and weak position power. $[1,2,4,8]$

5. Given the description of the finalists for the position of President at Northwest Community College, rate each one in terms of their LPC. Dr. Shepherd should be considered a High LPC. Dr. Cockerham should be considered a Low LPC. Dr. Miller should be considered a High LPC. $[1,4]$

6. According to Fiedler, which of the finalists would be the best choice to lead Northwest Community College?

Because of the current situation at Northwest Community College, Dr. Cockerham is the best choice. Dr. Cockerham is a Low LPC and should excel in an environment categorized as "least favorable" $[1,2,4]$

\section{Conclusions}

Every organization is progressing along a path to replace a leader. Even with a new hire, the progress has already started. It is critical that organizations look at their succession plans as a multi-faceted operation. Using Fiedler and Chemers Least Preferred Co-Worker inventory and the Contingency Theory approach, organizations can make a more predictable choice for candidates to lead their organization.

\section{References}

[1] DA CRUZ, MP; NUNES, AS; PINHEIRO, PG. Fiedler's Contingency Theory: Practical Application of the Least Preferred Coworker (LPC) Scale. IUP Journal of Organizational Behavior. 10, 4, 7, Oct. 2011. ISSN: 0972687X.

[2] Fiedler, F. E., Chemers, M. M. and Mahar, L. (1976) Improving Leadership Effectiveness: The Leader Match Concept, New York: John Wiley and Sons.

[3] FUSCH, PI; FUSCH, GE. Leadership and Conflict Resolution on the Production Line. International Journal of Applied Management \& Technology. 14, 1, 21, Jan. 2015. ISSN: 15444740.

[4] Northouse, P. G., (2012) Leadership: Theory and Practice $6^{\text {th }}$ Edition (Chapter 6).

[5] KESSLER, EH. Encyclopedia of Management Theory. Thousand Oaks, California: SAGE Publications, Inc, 2013. ISBN: 9781412997829.

[6] MITCHELL, TR; et al. The Contingency Model: Criticism and Suggestions. Academy of Management Journal. 13, 3, 253, Sept. 1970. ISSN: 00014273.

[7] NWAGBARA, U. Managing Organizational Change: Leadership, Tesco, and Leahy's Resignation. E Journal of Organizational Learning \& Leadership. 9, 1, 56, 2011. ISSN: 21548927.

[8] OC, B. Contextual leadership: A systematic review of how contextual factors shape leadership and its outcomes. The Leadership Quarterly. 29, 218-235, Feb. 1, 2018. ISSN: 1048-9843.

[9] WATERS, RD. The role of stewardship in leadershipApplying the contingency theory of leadership to relationship cultivation practices of public relations practitioners. Journal of Communication Management. 17, 4, 324, Nov. 2013. ISSN: 1363254X.

[10] WANG, G; HARMS, P; MACKEY, J. Does it take two to Tangle? Subordinates' Perceptions of and Reactions to Abusive Supervision. Journal of Business Ethics. 131, 2, 487, Oct. 2015. ISSN: 01674544 